\title{
Studies on Corrosion of Titanium and Air-Oxidized Titanium in Fluorinated Nitric Acid
}

\author{
J. Jayaraj ${ }^{1}$ (1) P. M. Ranjith ${ }^{2} \cdot$ S. Ningshen ${ }^{1} \cdot$ S. Ramanathan ${ }^{2}$
}

Received: 28 November 2018/ Accepted: 18 March 2019/Published online: 6 April 2019

(C) The Author(s) 2019

\begin{abstract}
Titanium (Ti) is a lustrous transition metal which possesses excellent corrosion resistance in several aggressive environments but is attacked by acidic fluoride media. In this work, the addition of fluoride ion to nitric acid on the corrosion behavior of $\mathrm{Ti}$ and air-oxidized $\mathrm{Ti}$ was studied. Air oxidation of $\mathrm{Ti}$ at $800{ }^{\circ} \mathrm{C}$ for $5 \mathrm{~h}$ resulted in the formation of an intact rutile $\mathrm{TiO}_{2}$ layer with a thickness of about $35 \mu \mathrm{m}$. The corrosion resistance was investigated from the polarization resistance $\left(R_{\mathrm{P}}\right)$ values which were obtained from linear polarization and electrochemical impedance spectroscopy (EIS) measurements. A decrease in the $R_{\mathrm{P}}$ value of Ti with the addition of fluoride ion in nitric acid was observed, and this indicated the formation of an unstable layer, which resulted in accelerated dissolution. The several order increase in the $R_{\mathrm{P}}$ value of air-oxidized $\mathrm{Ti}$ in nitric acid containing fluoride ions pointed the improved resistance to corrosion. The diffusivity of species through the air-oxidized $\mathrm{TiO}_{2}$ layer was estimated from the electrochemical equivalent circuit (EEC) analysis of EIS data. Even though the diffusivity
\end{abstract}

$\triangle$ J. Jayaraj

jrajb4u@gmail.com; jraj@igcar.gov.in

P. M. Ranjith

pmranjith10@gmail.com

S. Ningshen

ning@igcar.gov.in

S. Ramanathan

srinivar@iitm.ac.in

1 Corrosion Science and Technology Division, Indira Gandhi Centre for Atomic Research (IGCAR), Kalpakkam 603102, India

2 Department of Chemical Engineering, Indian Institute of Technology-Madras, Chennai 600036, India increased by several orders with the addition of fluoride ions, air-oxidized $\mathrm{Ti}$ provided better protection against nitric acid containing fluoride ions than Ti. The corrosion rates of $\mathrm{Ti}$ and air-oxidized $\mathrm{Ti}$ in boiling nitric acid containing fluoride ions were also estimated from weight loss experiments. Even in boiling fluorinated nitric acid, airoxidized $\mathrm{Ti}$ provided better corrosion protection, with corrosion rates of about 1000 times less than that of Ti.

Keywords Titanium - Air oxidation · Linear polarization . EIS · Weight loss measurement · Fluorinated nitric acid

\section{Introduction}

The compact reprocessing of advanced fuels in leadshielded cell (CORAL) facility at India utilizes commercially pure titanium grade 2 as dissolver vessel for the dissolution of spent mixed carbide fuels in boiling $11.5 \mathrm{M}$ nitric acid [1]. In contrast, Zirconium 702 is used as the dissolver and evaporator units of the La-Hague reprocessing plant, France [2]. Boiling $11.5 \mathrm{M} \mathrm{HNO}_{3}+0.05 \mathrm{M}$ $\mathrm{NaF}$ was proposed for the dissolution of spent mixed oxide $\left(72 \% \mathrm{UO}_{2}-28 \% \mathrm{PuO}_{2}\right)$ fuels, [3] and the addition of fluoride ions is highly necessary for its complete dissolution [4]. However, zirconium and titanium exhibited high corrosion resistance in boiling nitric acid, but showed poor corrosion in nitric acid containing fluoride ions [3, 5]. It was confirmed that the corrosion of zirconium was attributed to the formation of $\mathrm{ZrOF}_{2}$ and $\mathrm{ZrF}_{4}$ [3, 5]. Ti exhibited high corrosion resistance than zirconium alloy when exposed to boiling nitric acid containing fluoride ions with $\mathrm{ZrO}\left(\mathrm{NO}_{3}\right)_{3}$ as complexing agent [3]. At the boiling condition of $11.5 \mathrm{M} \mathrm{HNO}_{3}+0.05 \mathrm{M} \mathrm{NaF}$, the corrosion rate of $\mathrm{Ti}$ was reported to be $\sim 3.1 \mathrm{~mm} / \mathrm{y}$ [3]. For a 
thermosiphon-type Ti electrolytic dissolver vessel shown elsewhere [6], one of the critical parts is the Ti thermowell tube due to its very small wall thickness of about $0.9 \mathrm{~mm}$. Under the corrosive conditions, the estimated life of such Ti thermowell tube is about $\sim 0.29$ year, which is very small and unacceptable when compared to the life expectancy of a spent nuclear reprocessing plant. The polarization studies of Ti in $4.5 \mathrm{M} \mathrm{H}_{2} \mathrm{SO}_{4}+0.25 \mathrm{M} \mathrm{NaF}$ clearly showed the active and passive regions [7]. The anodic dissolution of $\mathrm{Ti}$ was studied by electrochemical impedance spectroscopy (EIS) technique in $1.0 \mathrm{M} \mathrm{HClO}_{4}$ with varying concentration of $\mathrm{NaF}$ from 0.001 to $0.1 \mathrm{M}$. At a $\mathrm{NaF}$ concentration $>0.001 \mathrm{M}$, dissolution of $\mathrm{Ti}$ was significant involving adsorbed intermediate species [8]. The dissolution of $\mathrm{Ti}$ in $1 \mathrm{M} \mathrm{Na}_{2} \mathrm{SO}_{4}+0.1 \mathrm{M} \mathrm{HF}$ was modeled with a four-step reaction mechanism involving $\mathrm{Ti}^{3+}$ and $\mathrm{Ti}^{4+}$ intermediate species [9]. All these studies confirmed that the presence of fluoride ion enhanced the dissolution of titanium.

To improve the corrosion and tribo-corrosion resistance of titanium and its alloys, several surface modification methods have been explored. Surface modification techniques such as chemical [10-12], electrochemical [13], sol-gel [14, 15], chemical vapor deposition [16], physical vapor deposition [17], plasma spray [18], ion implantation $[19,20]$, and air oxidation [21, 22] have been employed. Surface modification by air oxidation has been proposed to improve the corrosion resistance of $\mathrm{Ti}$ in the vapor phase of boiling nitric acid [23]. Also, argon-shrouded plasmasprayed tantalum coating has been developed as an overlay to improve the corrosion behavior of the $\mathrm{Ti}$ in nitric acid containing fluoride ions [24]. When compared to other surface modification techniques, air oxidation of $\mathrm{Ti}$ in a furnace at high temperatures is the simplest method to generate a protective $\mathrm{TiO}_{2}$ barrier layer.

Thus, in this work, to understand the electrochemical behavior, linear polarization and electrochemical impedance studies of the air-oxidized $\mathrm{Ti}$ were investigated and compared with the results of un-oxidized Ti, i.e., bare Ti. The electrochemical studies were carried out in nitric acid and nitric acid containing fluoride ions at room temperature. Further, the corrosion studies of air-oxidized $\mathrm{Ti}$ thermowells were evaluated in boiling nitric acid containing fluoride ions and compared with that of bare $\mathrm{Ti}$ thermowells.

\section{Materials and Methods}

Commercially pure titanium ( $\mathrm{Ti}$, grade 2 ) was used for evaluating the air oxidation behavior and its corrosion resistance in fluorinated nitric acid. Strip-shaped specimens of size $10 \mathrm{~mm} \times 10 \mathrm{~mm} \times 1.5 \mathrm{~mm}$ were made from $\mathrm{Ti}$ for the thermogravimetric analysis (TGA, Setsys 16/18, Setaram, France). The isothermal TGA experiments were carried out in a $20 \%$ oxygen environment to simulate an open-air condition. The TGA sample was heated from room temperature to $800{ }^{\circ} \mathrm{C}$ at $5{ }^{\circ} \mathrm{C} / \mathrm{min}$ and isothermally held at $800{ }^{\circ} \mathrm{C}$ for $5 \mathrm{~h}$. After TGA studies, the samples were allowed to cool in the TGA chamber to room temperature. Rod-shaped samples with a dimension of diameter $5 \mathrm{~mm} \times$ length $5 \mathrm{~mm}$ and thin-walled seamless tubes of thickness $0.9 \mathrm{~mm} \times$ outer diameter $17 \mathrm{~mm} \times$ length $11 \mathrm{~mm}$ were air-oxidized in a vertical furnace in atmospheric air. The rod and tube samples were heated from room temperature to $800{ }^{\circ} \mathrm{C}$ at $5{ }^{\circ} \mathrm{C} / \mathrm{min}$ and isothermally held at $800{ }^{\circ} \mathrm{C}$ for $5 \mathrm{~h}$. After air oxidation, the rod and tube samples were allowed to furnace-cool to room temperature. Before subjecting to the air oxidation process, strips, rods, and tubes of Ti samples were polished up to 1200 grit SiC paper and cleaned in ethanol. The air-oxidized samples were characterized using X-ray diffraction (XRD, Co $\mathrm{K} \alpha$, INEL) and field-emission scanning electron microscope (FE-SEM, Carl Zeiss Crossbeam 340).

The electrochemical experiments were performed with rod-shaped $\mathrm{Ti}$ and air-oxidized $\mathrm{Ti}$ working electrodes of diameter $5 \mathrm{~mm} \times$ length $5 \mathrm{~mm}$. The working electrodes were mounted into Teflon rods with only one face of the electrodes exposed to the electrolyte. The rotating disk electrode (Pine Instruments) setup was used to control the working electrode speed at $900 \mathrm{rpm}$. A platinum wire and $\mathrm{Ag} / \mathrm{AgCl}(3.5 \mathrm{M} \mathrm{KCl})$ were used as the counter and reference electrodes, respectively. The PARSTAT 2263 (Princeton Applied Research) potentiostat was used to conduct the electrochemical experiments. The electrolyte used was $11.5 \mathrm{M} \mathrm{HNO}_{3}$ and $11.5 \mathrm{M} \mathrm{HNO}_{3}+0.05 \mathrm{M} \mathrm{NaF}$ at room temperature. Before each experiment, the working electrodes were rinsed and ultrasonicated with ethanol.

The initial open-circuit potential (OCP) was measured, and it was observed that the stable OCP was achieved within $15 \mathrm{~min}$. The electrochemical experiments were performed after the stabilization of OCP. The linear polarization curve was obtained in a potential range of \pm $10 \mathrm{mV}$ versus OCP, at a scan rate of $0.5 \mathrm{mV} / \mathrm{s}$. SternGeary equation [25] could be used to estimate the polarization resistance $\left(R_{\mathrm{P}}\right)$ by Eq. 1 .

$R_{\mathrm{P}}=\frac{1}{i_{\text {corr }}}\left(E-E_{\text {corr }}\right)$

where $E$ is the potential, $E_{\mathrm{corr}}$ is the corrosion potential, and $i_{\text {corr }}$ is the corrosion current density. The electrochemical impedance spectroscopy (EIS) data were obtained by applying an AC perturbation of $20 \mathrm{mV}$ on the working electrode held at OCP. A frequency range $(100 \mathrm{kHz}-$ $10 \mathrm{mHz}$ ) with seven frequencies per decade (logarithmically spaced) was applied. Tafel extrapolation technique 
assumes that the electrode is not passivated at anodic potentials, whereas Ti passivates in nitric acid under anodic conditions [9]. In case of air-oxidized Ti, active dissolution is not expected even at OCP. Since the assumptions employed in the Tafel extrapolation are not satisfied, potentiodynamic polarization and Tafel extrapolation are not used to estimate the corrosion rate in this work. The polarization resistance $\left(R_{\mathrm{P}}\right)$ measured from linear polarization data under rotating $(900 \mathrm{rpm})$ and non-rotating conditions were used to study the effect of hydrodynamics on dissolution. The impedance experiments were conducted only at rotating conditions to eliminate the mass transfer limitations in the electrolyte. The $R_{\mathrm{P}}$ value of the air-oxidized $\mathrm{Ti}$ sample obtained from linear polarization and electrochemical impedance was compared with that of the un-oxidized $\mathrm{Ti}$, i.e., bare Ti.

The weight loss experiments were performed for both $\mathrm{Ti}$ and air-oxidized Ti tubes in $11.5 \mathrm{M} \mathrm{HNO}_{3}+0.05 \mathrm{M} \mathrm{NaF}$ solution at room $\left(25^{\circ} \mathrm{C}\right)$ and boiling $\left(120^{\circ} \mathrm{C}\right)$ temperatures. By following the ASTM A262 Practice $\mathrm{C}$ procedure [26], the tube samples were exposed for a period of $48 \mathrm{~h}$ in boiling $11.5 \mathrm{M} \mathrm{HNO}_{3}+0.05 \mathrm{M} \mathrm{NaF}$ solution, and the vapors produced were refluxed using a cold finger setup. After each test period of $48 \mathrm{~h}$, the tube samples were removed, cleaned with distilled water, and air-dried, and the change in weight was measured in a microbalance. After every $48 \mathrm{~h}$, the fresh electrolyte was used, and the samples were exposed for a total exposure period of $240 \mathrm{~h}$. The corrosion rates from weight loss measurements were calculated using Eq. 2.

Corrosion rate $=\frac{8.76 \times 10^{4} \times W}{\rho \times A \times t}$

where the corrosion rate is expressed in $\mathrm{mm} / \mathrm{y}, W$ is weight loss in $\mathrm{g}, \rho$ is the density of the sample (Ti: $4.5 \mathrm{~g} \mathrm{~cm}^{-3}$, $\left.\mathrm{TiO}_{2}: 4.23 \mathrm{~g} \mathrm{~cm}^{-3}\right), A$ is the exposed surface area in $\mathrm{cm}^{2}$, and $t$ is exposed time in $\mathrm{h}$. It is worth mentioning that for the electrochemical and weight loss studies, in case of the oxidized sample, no further polishing was carried out, i.e., as-oxidized condition was used, and for the bare Ti samples polishing up to 1200 grit $\mathrm{SiC}$ paper was maintained.

\section{Results and Discussion}

\subsection{Characterization of Air-Oxidized Ti}

The mass gain data obtained by the thermogravimetric study of $\mathrm{Ti}$ at $800{ }^{\circ} \mathrm{C}$ for $5 \mathrm{~h}$ is shown in Fig. 1. During the isothermal study, the power law (Eq. 3) is used to describe the mass gain behavior of $\mathrm{Ti}$

$\Delta m=k t^{n}$

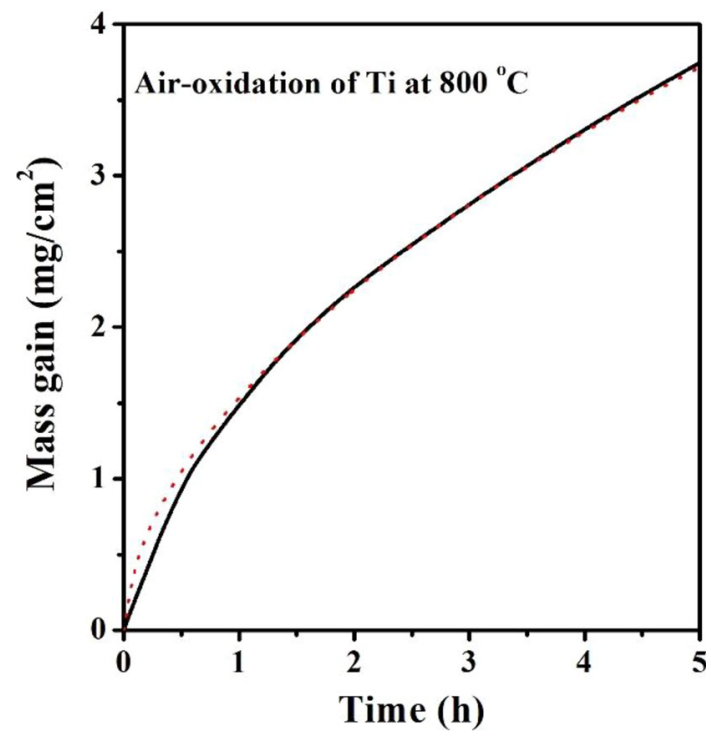

Fig. 1 Isothermal TGA behavior of $\mathrm{Ti}$ at $800{ }^{\circ} \mathrm{C}$ for $5 \mathrm{~h}$ in a $20 \%$ oxygen environment to simulate an open-air condition. Experimental results are shown as continuous lines, and the best-fitted line is shown as a dotted line

where $\Delta m$ is the mass gain/total surface area $\left(\mathrm{mg} \mathrm{cm}^{-2}\right)$, $k$ is the rate constant $\left(\mathrm{mg} \mathrm{cm}^{-2} \mathrm{~h}^{-1}\right), \mathrm{t}$ is isothermal holding time (h), and $n$ is the exponent value for t. The best-fitted power law curve is plotted as a dotted line (Fig. 1), and the fitted $k$ and $n$ values are $1.54 \mathrm{mg} \mathrm{cm}^{-2}$ $\mathrm{h}^{-1}$ and 0.55 , respectively. It is seen that the model fit is very good and only slight deviations are observed in the initial stage. The $n$ value is close to 0.5 , representing a near-parabolic growth law. The pioneering work of Kofstad et al. has described the effect of oxidation temperature on the rate laws of oxide growth on the titanium [27]. It has been identified that if the oxidation temperature $>1000{ }^{\circ} \mathrm{C}$, the mass gain obeys the linear law and results in spallation of the un-protective thick $\mathrm{TiO}_{2}$ layer. On the other hand, if the oxidation temperature is in the range of $600-850{ }^{\circ} \mathrm{C}$, the mass gain obeys parabolic rate law and results in the formation of protective rutile $\mathrm{TiO}_{2}$. Due to the parabolic growth, a protective and intact oxide layer of a thickness of about $35 \mu \mathrm{m}$ as shown in Fig. 2a is observed. The formations of the dense and faceted morphology of the rutile $\mathrm{TiO}_{2}$ phase is observed in SEM (Fig. 2b) and is confirmed by XRD analysis (JCPDF PDF\#898304) (Fig. 2c). The oxidized rod and thin tube samples also exhibit similar rutile pattern and morphology.

\subsection{Linear Polarization Behavior of Ti and Air- Oxidized Ti}

The linear polarization curves for the bare $\mathrm{Ti}$ in nitric acid (Fig. 3a) and nitric acid containing fluoride ions (Fig. 3b) 


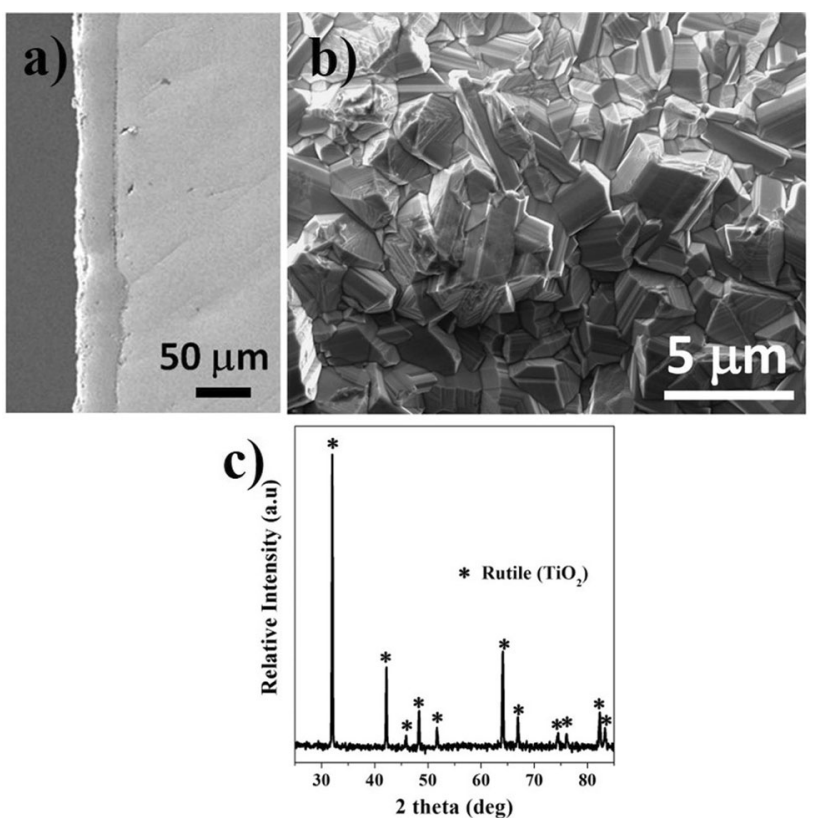

Fig. 2 SEM micrograph of air-oxidized Ti a cross section $\mathbf{b}$ surface morphology, and $\mathbf{c}$ XRD results of air-oxidized $\mathrm{Ti}$

at room temperature have been recorded at both rotating and non-rotating conditions. Figure $3 \mathrm{a}, \mathrm{b}$ show the linear relationship between the current density and potential for $\mathrm{Ti}$ in both the test solutions. The $R_{\mathrm{P}}$ values estimated from the reciprocal of the slopes of the linear polarization curves (Fig. 3a, b) are given in Table 1 . When compared to $R_{\mathrm{P}}$ value in the nitric acid environment, the value obtained in nitric acid containing fluoride ions is about 150 times smaller with rotation and about 45 times smaller without rotation. The large $R_{\mathrm{P}}$ values obtained for Ti in nitric acid $\left(\sim 4.4 \times 10^{3} \Omega \mathrm{cm}^{2}\right)$ indicate the high corrosion resistance of $\mathrm{Ti}$ which is attributed to the formation of a thin passive film of $\mathrm{TiO}_{2}$ as shown in Eq. 4 [28, 29].

$$
\begin{aligned}
3 \mathrm{Ti}+4 \mathrm{HNO}_{3} & \leftrightarrow 3 \mathrm{TiO}_{2}+4 \mathrm{NO}+2 \mathrm{H}_{2} \mathrm{O} ; \Delta G_{r}^{0} / \mathrm{kJ} \mathrm{mol}^{-1} \\
& =-846
\end{aligned}
$$

where $\Delta G_{r}^{0}$ is the standard Gibbs free energy change for the reaction ( $r$ ) and it is calculated using the standard free energy values [30] for the products and reactants of the reaction under standard conditions. The negative sign indicates that the reaction proceeds spontaneously, and the highest value is the most favorable one. For the Ti in nitric acid, the obtained $E_{\text {corr }}(\sim 900 \mathrm{mV})$ and $R_{\mathrm{P}}$ values are similar under rotating and non-rotating conditions, which indicates that the passive film formation is not significantly affected by the hydrodynamic effect. As the dissolution of $\mathrm{Ti}$ in nitric acid is very low, the process will be reactioncontrolled, not mass transfer-controlled and will not be affected by the rotation of the electrode. The lower $R_{\mathrm{P}}$ value of $\mathrm{Ti}$ in nitric acid containing fluoride ions compared to non-fluorinated nitric acid indicates that the $\mathrm{TiO}_{2}$ film is unstable and its breakdown results in the dissolution of $\mathrm{Ti}$ in nitric acid containing fluoride ions as shown in Eqs. 5 and $6[3]$.

$$
\begin{aligned}
\mathrm{Ti}+2 \mathrm{NaF}+2 \mathrm{HNO}_{3} \leftrightarrow & \mathrm{TiO}_{2}+2 \mathrm{NaNO}_{2} \\
& +2 \mathrm{HF} ; \Delta G_{r}^{0} / \mathrm{kJ} \mathrm{mol}^{-1} \\
= & -787 \\
\mathrm{Ti}+6 \mathrm{NaF}+6 \mathrm{HNO}_{3} \leftrightarrow & \mathrm{TiF}_{4}+4 \mathrm{NaNO}_{3}+2 \mathrm{NaNO}_{2} \\
& +2 \mathrm{HF} ; \Delta G_{r}^{0} / \mathrm{kJ} \mathrm{mol}^{-1} \\
= & -915
\end{aligned}
$$

The $R_{\mathrm{P}}$ value of Ti in nitric acid containing fluoride ions with the rotation of the electrode $\left(27.9 \Omega \mathrm{cm}^{2}\right)$ has been found to be three times smaller than that without rotation (94.7 $\Omega \mathrm{cm}^{2}$ ). This indicates that the dissolution is enhanced with the rotation of the electrode. The $\mathrm{Ti}$ is expected to form $\mathrm{TiF}_{4}$ while reacting with nitric acid containing fluoride ions and goes into the solution more likely in the form of $\mathrm{TiF}_{6}^{2-}$ ions $[3,8,31]$. Under non-
Fig. 3 Linear polarization behavior of $\mathrm{Ti}$ at room temperature in a $11.5 \mathrm{M} \mathrm{HNO}_{3}$ and b $11.5 \mathrm{M} \mathrm{HNO}_{3}+0.05 \mathrm{M}$ $\mathrm{NaF}$ at a scan rate of $0.5 \mathrm{mV} / \mathrm{s}$
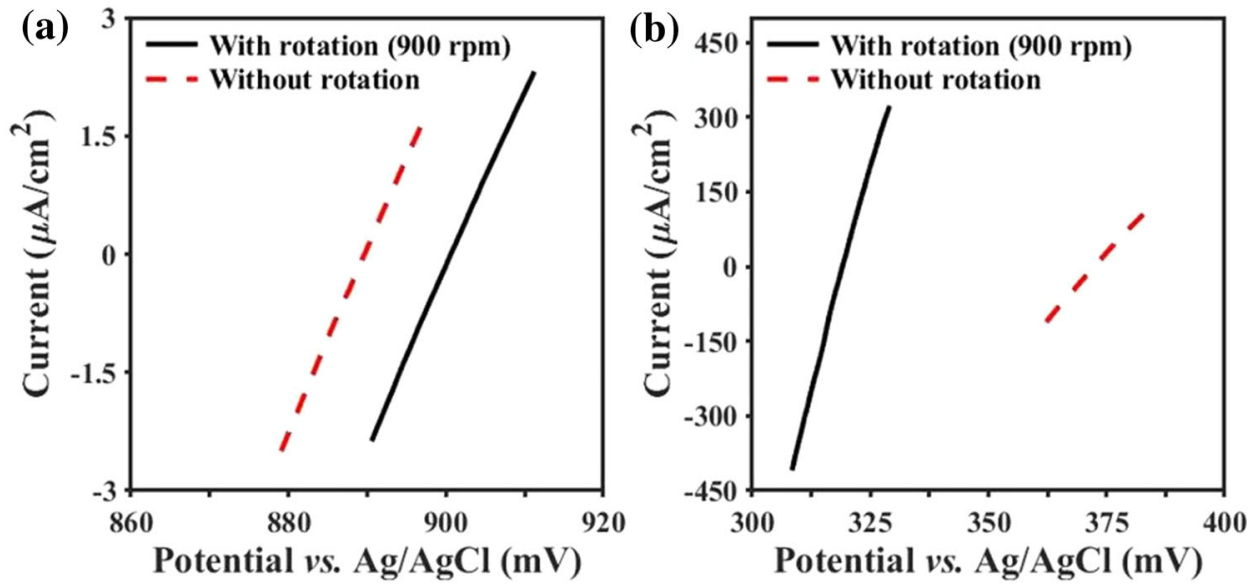
Table 1 Linear polarization parameters of Ti and air-oxidized $\mathrm{Ti}$ (rutile $\mathrm{TiO}_{2}$ ) obtained in $11.5 \mathrm{M} \mathrm{HNO}_{3}$ and $11.5 \mathrm{M} \mathrm{HNO}_{3}+0.05 \mathrm{M} \mathrm{NaF}$ at room temperature

\begin{tabular}{|c|c|c|c|c|c|}
\hline \multirow[t]{2}{*}{ Material } & \multirow[t]{2}{*}{ Environment } & \multicolumn{2}{|c|}{$\begin{array}{l}\mathrm{E}_{\text {corr }} \\
\mathrm{mV} \text { versus } \mathrm{Ag} / \mathrm{AgCl}\end{array}$} & \multicolumn{2}{|l|}{$\begin{array}{l}R_{\mathrm{P}} \\
\Omega . \mathrm{cm}^{2}\end{array}$} \\
\hline & & Without rotation & With rotation $(900 \mathrm{rpm})$ & Without rotation & With rotation $(900 \mathrm{rpm})$ \\
\hline \multirow[t]{2}{*}{$\mathrm{Ti}$} & $11.5 \mathrm{M} \mathrm{HNO}_{3}$ & 889 & 900 & $\begin{array}{l}4319.33 \\
(0.53 \%)\end{array}$ & $\begin{array}{l}4414.92 \\
(0.81 \%)\end{array}$ \\
\hline & $11.5 \mathrm{M} \mathrm{HNO}_{3}+0.05 \mathrm{M} \mathrm{NaF}$ & 373 & 315 & $\begin{array}{l}94.70 \\
(0.89 \%)\end{array}$ & $\begin{array}{l}27.9 \\
(1.68 \%)\end{array}$ \\
\hline \multirow[t]{2}{*}{$\begin{array}{l}\text { Air-oxidized Ti } \\
\left(\text { Rutile } \mathrm{TiO}_{2}\right)\end{array}$} & $11.5 \mathrm{M} \mathrm{HNO}_{3}$ & 161 & 156 & $\begin{array}{l}9.10 \times 10^{4} \\
(0.85 \%)\end{array}$ & $\begin{array}{l}7.26 \times 10^{4} \\
(0.87 \%)\end{array}$ \\
\hline & $11.5 \mathrm{M} \mathrm{HNO}_{3}+0.05 \mathrm{M} \mathrm{NaF}$ & 137 & 138 & $\begin{array}{l}5.07 \times 10^{4} \\
(0.55 \%)\end{array}$ & $\begin{array}{l}5.20 \times 10^{4} \\
(0.46 \%)\end{array}$ \\
\hline
\end{tabular}

rotating conditions, the corroded products on the surface can hinder the mass transfer of fresh nitric acid containing fluoride ions on to the surface of the metal electrode and thereby reduce the dissolution of Ti. With the rotation of electrode, the $\mathrm{TiF}_{4}$ may quickly move into the bulk of the solution, and a uniform concentration of nitric acid containing fluoride ions can be maintained on the surface of the electrode, and thereby increase the dissolution rate.

The linear polarization curves for the air-oxidized $\mathrm{Ti}$ (Rutile $\mathrm{TiO}_{2}$ ) in nitric acid (Fig. 4a) and nitric acid containing fluoride ions (Fig. 4b) are recorded at room temperature with and without rotation, and the obtained $R_{\mathrm{P}}$ values are shown in Table 1 . There is no significant difference in $R_{\mathrm{P}}$ values of air-oxidized $\mathrm{Ti}$ in nitric acid ( $\sim 8 \times 10^{4} \Omega \mathrm{cm}^{2}$ ) under rotating and non-rotating conditions. The addition of fluoride in nitric acid slightly reduces the $R_{\mathrm{P}}$ value of air-oxidized $\mathrm{Ti}\left(\sim 5 \times 10^{4} \Omega\right.$ $\mathrm{cm}^{2}$ ). This is probably due to the attack of fluoride ions through the thick rutile $\mathrm{TiO}_{2}$ oxide layer. Under the rotating condition, the $R_{\mathrm{P}}$ value of air-oxidized Ti in nitric acid and nitric acid containing fluoride ions is about 16 and
1863 times higher than that of bare Ti, respectively. The several order increase in $R_{\mathrm{P}}$ value of air-oxidized $\mathrm{Ti}$ in nitric acid containing fluoride ions points to the significant corrosion protection offered by the air-oxidized rutile $\mathrm{TiO}_{2}$ on the surface of Ti.

\subsection{Electrochemical Impedance Analysis of Ti and Air-Oxidized Ti}

The electrochemical impedance spectra of bare Ti rotating at $900 \mathrm{rpm}$ have been recorded at the corresponding OCP values in nitric acid and nitric acid containing fluoride ions, and the respective results are shown in Nyquist plots (Figs. 5a and 6a). The experimental data are shown as markers, while the EEC model results, described below, are shown in dashed lines. For the EEC modeling, Zsimpwin ${ }^{\circledR}$ software (Princeton Applied Research, USA) has been used. The results of linear polarization experiments show that, under stationary conditions, mass transfer of active species in the electrolyte limits the net reaction rate. When mass transfer in solution is coupled with reaction on $\mathrm{Ti}$ and
Fig. 4 Linear polarization behavior of air-oxidized $\mathrm{Ti}$ at room temperature in a $11.5 \mathrm{M}$ $\mathrm{HNO}_{3}$ and b $11.5 \mathrm{M}$

$\mathrm{HNO}_{3}+0.05 \mathrm{M} \mathrm{NaF}$ at a scan rate of $0.5 \mathrm{mV} / \mathrm{s}$
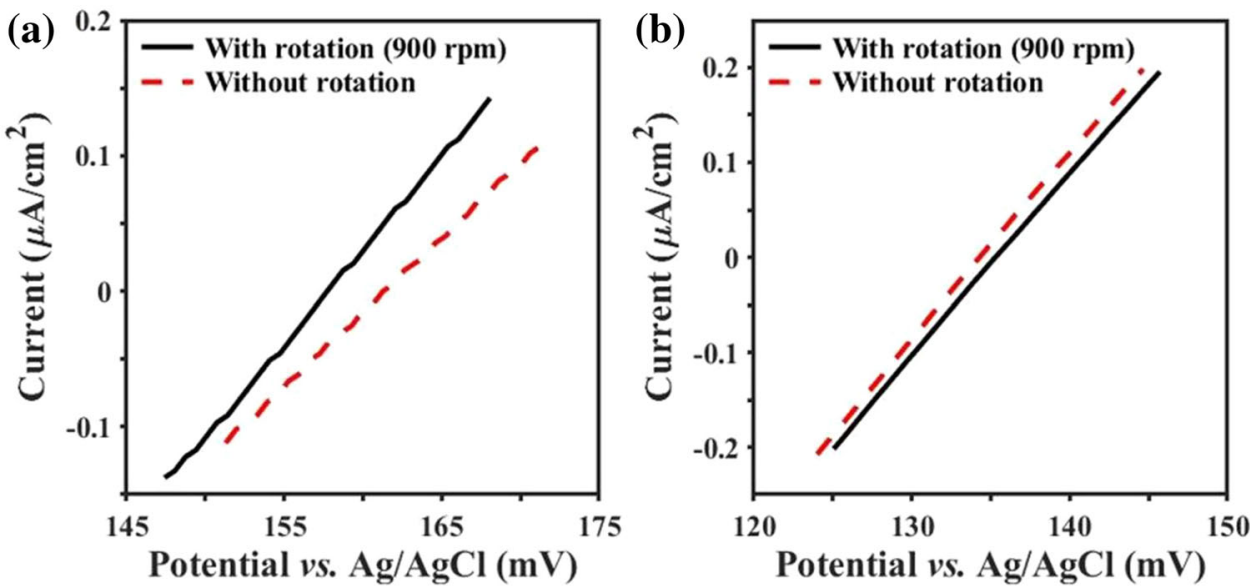


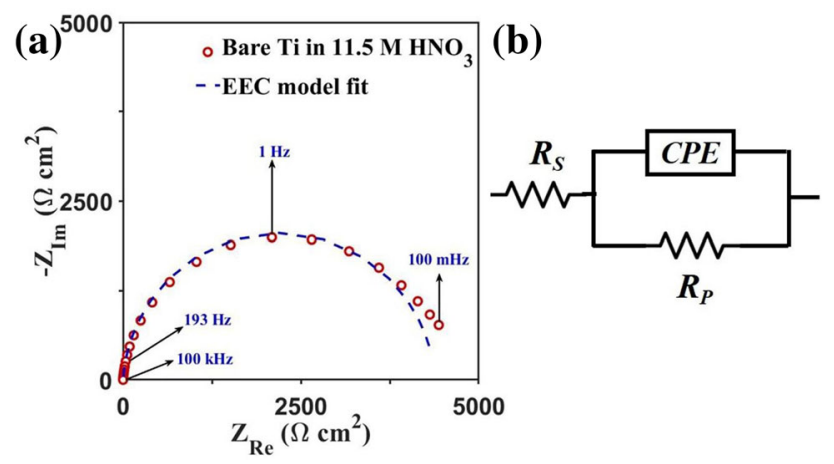

Fig. 5 Electrochemical impedance behavior of bare $\mathrm{Ti}$ (with a rotational speed of $900 \mathrm{rpm}$ ) held at $\mathrm{OCP}$ in $11.5 \mathrm{M} \mathrm{HNO}_{3}$ at room temperature a Nyquist plot and $\mathbf{b}$ EEC used to model the data
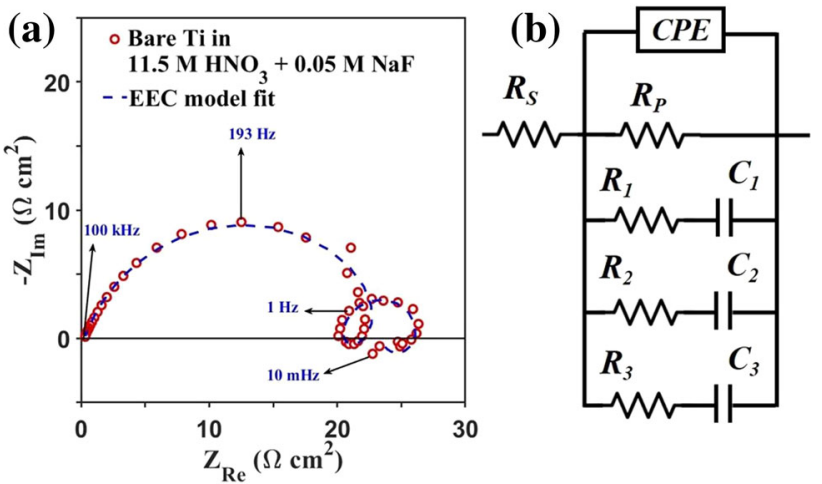

Fig. 6 Electrochemical impedance behavior of bare $\mathrm{Ti}$ (with a rotational speed of $900 \mathrm{rpm}$ ) held at $\mathrm{OCP}$ in $11.5 \mathrm{M} \mathrm{HNO}_{3}+0.05 \mathrm{M}$ $\mathrm{NaF}$ at room temperature $\mathbf{a}$ Nyquist plot and $\mathbf{b}$ EEC used to model the data

possible mass transfer in the film in case of air-oxidized $\mathrm{Ti}$, the analysis becomes very challenging. Hence, EIS experiments are performed only under rotating conditions so that the results can be analyzed assuming rapid mass transfer in the electrolyte. In nitric acid, the impedance spectra of Ti (Fig. 5a) show only one capacitance loop in the frequency range studied. The capacitance loop is a depressed semicircle and has been analyzed using an equivalent circuit of $R_{\mathrm{S}}\left(Q R_{\mathrm{P}}\right)$, as shown in Fig. 5b. Here, $R_{\mathrm{S}}$ is the solution resistance, $Q$ is the constant phase element (CPE), and $R_{\mathrm{P}}$ is the polarization resistance. $Q$ has been used in the present investigation to obtain a better fit for the experimental data $[32,33]$. The impedance of $Q$ is given in Eq. 7.

$Z_{Q}=Y_{0}^{-1}(j \omega)^{-n}$

where $Y_{0}$ is a constant $\left(\Omega^{-1} s^{n}\right), \mathrm{n}$ is the power index value of $Q, \omega$ is the angular frequency, and $j$ is the imaginary number equal to $\sqrt{-1}$. The effective capacitance $\left(C_{\text {eff }}\right)$ is determined using Brug's formula [32] (Eq. 8).
$C_{\text {eff }}=\left[Y_{0}\left(\frac{1}{R_{S}}+\frac{1}{R_{P}}\right)^{n-1}\right]^{1 / n}$

The estimated $C_{\text {eff }}$ is given in Table 2. The thickness (d) of the passive film that forms on Ti in nitric acid has been calculated using Eq. 9 [34].

$d=\frac{\varepsilon \varepsilon_{o}}{C_{\text {eff }}}$

where $\varepsilon$ is the dielectric constant of the passive film ( $\varepsilon$ for $\mathrm{TiO}_{2}$ is 25) and $\varepsilon_{o}=8.854 \times 10^{-14} \mathrm{~F} \mathrm{~cm}^{-1}$ is the permittivity of free space charge. The calculated thickness of the passive film formed on $\mathrm{Ti}$ at the OCP condition in nitric acid is much lower $(\sim 0.9 \mathrm{~nm})$ compared to that of the oxide layer formed due to air oxidation. The $R_{\mathrm{P}}$ values are estimated based on the condition given in Eq. 10.

$R_{P}=\lim _{\omega \rightarrow 0} Z_{F}$

where $Z_{F}$ is the faradaic impedance. The estimated $R_{\mathrm{P}}$ value, from EEC fit, of Ti in nitric acid is given in Table 2. A comparison of Table 1 and 2 shows that $R_{\mathrm{P}}$ estimated from LP and EIS shows a good match. The very high $R_{\mathrm{P}}$ value $\left(\sim 4.4 \times 10^{3} \Omega \mathrm{cm}^{2}\right)$ indicates that the passive film formed on $\mathrm{Ti}$ is highly protective in nitric acid even if it is very thin.

The impedance spectrum obtained for $\mathrm{Ti}$ in nitric acid containing fluoride ions (Fig. 6a) shows a high-frequency capacitive loop, an inductive loop, and a capacitive loop at mid frequencies and another inductive loop at the low frequencies. The double layer that is formed at the interface of electrode surface and electrolyte, in parallel with the $R_{\mathrm{P}}$, is responsible for the measured capacity loop at the higher frequencies. The observed inductive loops can be treated as inductance or negative capacitance $[35,36]$. The inductance arises from the electrochemical reactions with formation of intermediate adsorbed species and their relaxation [37, 38]. An equivalent circuit with three adsorbed intermediates has been used for the analysis of EIS data (Fig. 6b). While fitting the impedance data, $C_{1} R_{1}$ and $C_{2} R_{2}$ of Fig. $6 \mathrm{~b}$ are allowed to hold negative values to represent the inductance. Previously, the dissolution of Ta, $\mathrm{Nb}, \mathrm{Zr}$, and Ti in HF has been observed and modeled with inductive loops of EIS data [9, 39-41]. The two inductance loops and the mid-frequency capacitance loop obtained (Fig. 6b) can be ascribed to the relaxation of adsorbed intermediate species. The best-fit EEC parameters are listed in Table 3. It is challenging to obtain physical insights for the Maxwell elements, and since the focus is on corrosion resistance, only $R_{\mathrm{P}}$ values have been used for further analysis. A comparison of Table 1 and Table 3 shows that $R_{\mathrm{P}}$ values of $\mathrm{Ti}$ in nitric acid containing fluoride ions 
Table 2 Best-fit EEC parameters for Ti (with a rotational speed of $900 \mathrm{rpm}$ ) held at OCP in $11.5 \mathrm{M} \mathrm{HNO}_{3}$ at room temperature

\begin{tabular}{llllll}
\hline OCP & $R_{\mathrm{S}}$ & $Y_{0}$ & $n$ & $C_{\text {eff }}$ & $R_{\mathrm{P}}$ \\
\hline $\mathrm{mV}$ vs Ag/AgCl & $\Omega \mathrm{cm}^{2}$ & $\Omega^{-1} \mathrm{~cm}^{-2} \mathrm{~S}^{\mathrm{n}}$ & - & $\mu \mathrm{F} \mathrm{cm}$ & $\Omega \mathrm{cm}^{2}$ \\
900 & 0.35 & $3.92 \times 10^{-5}$ & 0.96 & 24.58 & 4407 \\
& $(2 \%)$ & $(2 \%)$ & $(<1 \%)$ & $(2 \%)$ \\
\hline
\end{tabular}

Table 3 Best-fit EEC parameters for Ti (with a rotational speed of $900 \mathrm{rpm}$ ) held at OCP in $11.5 \mathrm{M} \mathrm{HNO}_{3}+0.05 \mathrm{M}$ NaF at room temperature

\begin{tabular}{llllllllllll}
\hline OCP & $R_{\mathrm{S}}$ & $Y_{0}$ & $n$ & $C_{1}$ & $R_{1}$ & $C_{2}$ & $R_{2}$ & $C_{3}$ & $R_{3}$ & $C_{\text {eff }}$ & $R_{\mathrm{P}}$ \\
\hline $\mathrm{mV}$ vs Ag/AgCl & $\Omega \mathrm{cm}^{2}$ & $\Omega^{-1} \mathrm{~cm}^{-2} \mathrm{~S}^{\mathrm{n}}-$ & $\mathrm{mF} \mathrm{cm} \mathrm{cm}^{-2}$ & $\Omega \mathrm{cm}^{2}$ & $\mathrm{mF} \mathrm{cm}$ & $\Omega \mathrm{cm}^{2}$ & $\mathrm{mF} \mathrm{cm}^{-2}$ & $\Omega \mathrm{cm}^{2}$ & $\mu \mathrm{F} \mathrm{cm}$ & $\Omega \mathrm{cm}^{2}$ \\
315 & 0.26 & $1.65 \times 10^{-4}$ & 0.78 & 6.37 & 78.34 & -0.14 & -97.64 & -26.33 & -164.60 & 9.65 & 23.34 \\
& $(3 \%)$ & $(6 \%)$ & $(<1 \%)$ & $(29 \%)$ & $(12 \%)$ & $(21 \%)$ & $(10 \%)$ & $(39 \%)$ & $(25 \%)$ & $(2 \%)$ \\
\hline
\end{tabular}

estimated from EIS and LP match well. While the $R_{\mathrm{P}}$ value of $\mathrm{Ti}$ in nitric acid is high, it decreases dramatically with the addition of NaF. A similar trend is also observed in $R_{\mathrm{P}}$ values obtained from LP.

The impedance spectra obtained for air-oxidized $\mathrm{Ti}$ rotating at $900 \mathrm{rpm}$ in nitric acid and nitric acid containing fluoride ions are shown in Fig. 7a and Fig. 7b, respectively.
The experimental data and EEC model results are shown as markers and dotted line, respectively. Here, it is assumed that the diffusion of ionic species through the air-oxidized layer influences the impedance of air-oxidized $\mathrm{Ti}$ under rotating condition. Analyses using simpler circuits result in poor fit to the experimental data and hence have not been pursued further. In nitric acid, the impedance spectra of air-
Fig. 7 Electrochemical impedance behavior of airoxidized $\mathrm{Ti}$ (with a rotational speed of $900 \mathrm{rpm}$ ) held at OCP in a $11.5 \mathrm{M} \mathrm{HNO}_{3}$ b $11.5 \mathrm{M}$ $\mathrm{HNO}_{3}+0.05 \mathrm{M} \mathrm{NaF}$ at room temperature and $\mathbf{c}$ EEC used to model the data
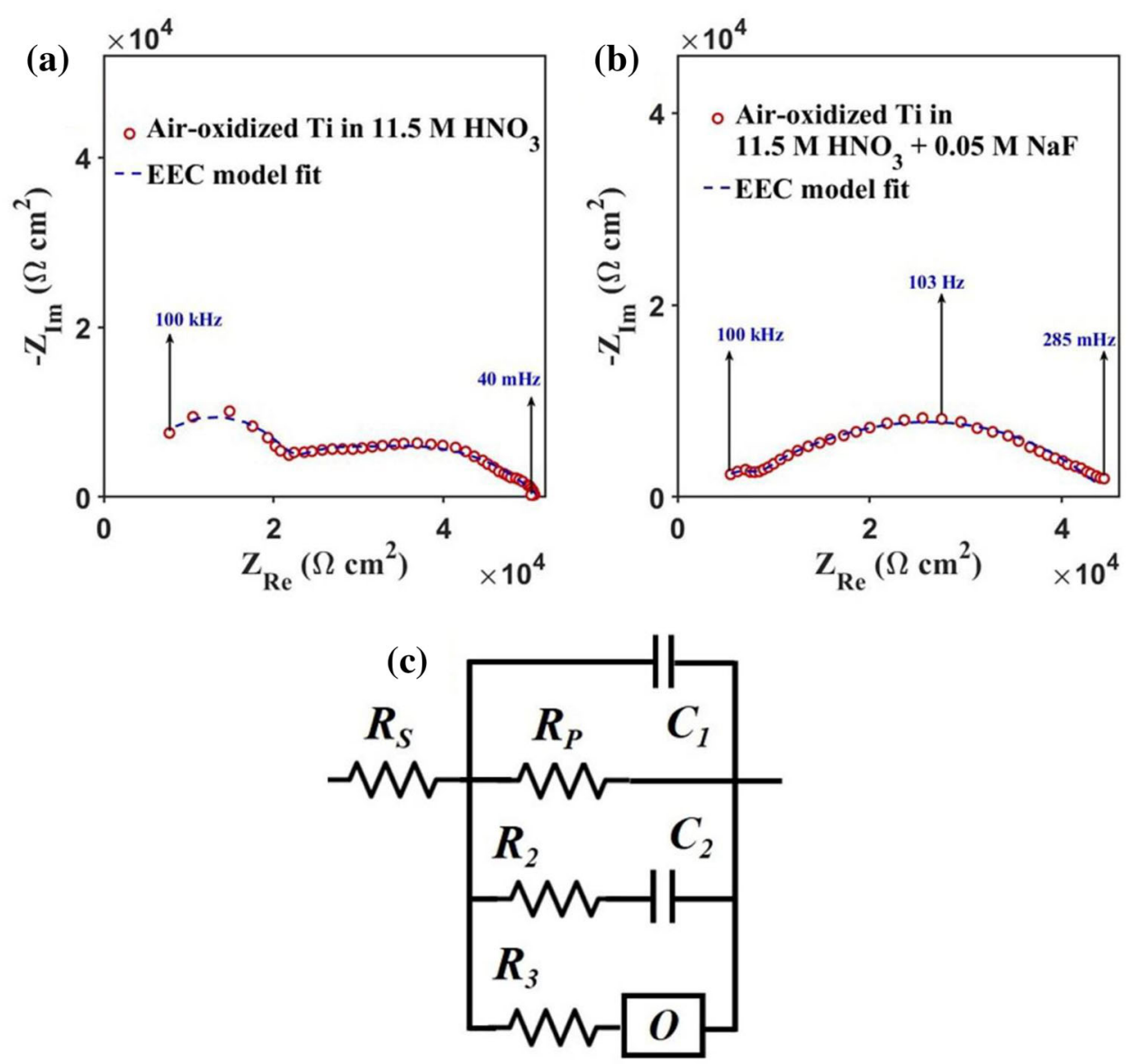
oxidized Ti (Fig. 7a) show two different capacitance loops, one in the high and the other in low-frequency range, respectively. The capacity loop observed at the high frequency corresponds to the double layer that is formed at the interface of electrode surface and electrolyte, in parallel with the $R_{\mathrm{P}}$. The capacitance loop with depressed semicircle has been analyzed using an equivalent circuit of $R_{\mathrm{S}}\left(C_{1} R_{\mathrm{P}}\right)$, as shown in Fig. 7c. Conversely, the low-frequency loop is modeled with a parallel combination of $\mathrm{C}_{2} R_{2}$ and $\mathrm{OR}_{3}$. The element " $O$ " represents the finitelength linear diffusion with the transmissive boundary condition, also known as bounded Warburg element, and the impedance $\left(Z_{\mathrm{BW}}\right)$ for this diffusion is given in Eq. 11 $[35,36]$.

$Z_{\mathrm{BW}}=\frac{\sigma}{\sqrt{\omega}} \tanh \left(\sqrt{\frac{j \omega}{D}} l\right)(1-j)=\frac{\sigma}{\sqrt{j \omega}} \tanh \left(\sqrt{\frac{j \omega}{D} l}\right)$

where $D$ is the diffusivity of reacting species, $l$ is the thickness of the air-oxidized layer, and $\sigma$ is the mass transfer coefficient. A similar circuit with an inductorbased Maxwell element has been used earlier to model the hydrogen oxidation in fuel cell [42]. The parameters estimated from EEC model are listed in Table 4. The parameters $Y_{0}$ and $B$ corresponds to the Maxwell element $O$, and Eq. 11 can be rewritten as

$Z_{\mathrm{BW}}=\frac{1}{Y_{0} \sqrt{j \omega}} \tanh (B \sqrt{j \omega})$

The diffusivity of reacting species through the airoxidized layer is determined from the finite-length reflective impedance parameter $B$ as shown in Eq. 13 .

$D=\left(\frac{l}{B}\right)^{2}$

The impedance spectrum of air-oxidized $\mathrm{Ti}$ in nitric acid containing fluoride ions shows a very small capacitive loop at high frequency and another loop at a low frequency similar to $\mathrm{Ti}$. The impedance spectra are modeled with the circuit shown in Fig. 7c. The corresponding estimated EEC parameters are listed in Table 4 . The $R_{\mathrm{P}}$ values estimated form LP and EIS are in the same range of a few $10^{4} \Omega \mathrm{cm}^{2}$ for air-oxidized Ti in both nitric acid and fluorinated nitric acid. This indicates that the oxide layer formed as a result of air oxidation at $800{ }^{\circ} \mathrm{C}$ is highly protective. For the air-oxidized $\mathrm{Ti}$ electrode immersed in nitric acid, the estimated diffusivity of reacting species through the film is obtained to be very low (of the order of $10^{-16} \mathrm{~cm}^{2} \mathrm{~s}^{-1}$ ). On the other hand, when the same electrode is immersed in fluorinated nitric acid, the estimated diffusivity in the film is relatively higher of the order of $10^{-6} \mathrm{~cm}^{2} \mathrm{~s}^{-1}$ (Table 4). It is likely that the oxide layer is attacked by the nitric acid containing fluoride ions (Eq. 14) [3], and the increas in defects may have caused an increase in the estimated diffusivity value.

$$
\begin{aligned}
\mathrm{TiO}_{2}+4 \mathrm{NaF}+4 \mathrm{HNO}_{3} \leftrightarrow & \mathrm{TiF}_{4}+4 \mathrm{NaNO}_{3} \\
& +2 \mathrm{H}_{2} \mathrm{O} ; \Delta G_{r}^{0} / \mathrm{kJ} \mathrm{mol}^{-1} \\
= & -128
\end{aligned}
$$

\subsection{Weight Loss Measurements in Nitric Acid Containing Fluoride Ions}

The corrosion rates of $\mathrm{Ti}$ and air-oxidized $\mathrm{Ti}$ in nitric acid containing fluoride ions under room temperature and boiling conditions are shown in Table 5. In the given test solution, the corrosion rate of $\mathrm{Ti}$ under room temperature has been determined to be $0.15 \mathrm{~mm} / \mathrm{y}$, but it increases to more than 23 times under boiling condition. The as-polished Ti exhibits a metallic luster as shown in Fig. 8a. The thickness of Ti tubes get considerably reduced (Fig. 8b) when exposed in boiling fluorinated nitric acid for $48 \mathrm{~h}$. The dissolution behavior of the bare $\mathrm{Ti}$, when exposed to boiling fluorinated nitric acid, is likely due to the formation of $\mathrm{TiF}_{4}$, as shown in Eq. 6.

\begin{tabular}{|c|c|c|c|c|c|c|c|c|c|c|}
\hline Solution & $\begin{array}{l}\text { OCP } \\
\mathrm{mV} \\
\mathrm{vs} \\
\mathrm{Ag} / \\
\mathrm{AgCl}\end{array}$ & $\begin{array}{l}R_{\mathrm{S}}+R_{\mathrm{film}} \\
\Omega \mathrm{cm}^{2}\end{array}$ & $\begin{array}{l}C_{1} \\
\mathrm{~F} \mathrm{~cm}^{-2}\end{array}$ & $\begin{array}{l}C_{2} \\
\mathrm{~F} \mathrm{~cm}^{-2}\end{array}$ & $\begin{array}{l}R_{2} \\
\Omega \mathrm{cm}^{2}\end{array}$ & $\begin{array}{l}O-Y_{0} \\
\Omega^{-1} \mathrm{~s}^{1 / 2}\end{array}$ & $\underset{\mathrm{s}^{1 / 2}}{O-B}$ & $\begin{array}{l}R_{3} \\
\Omega \mathrm{cm}^{2}\end{array}$ & $\begin{array}{l}R_{\mathrm{P}} \\
\Omega \mathrm{cm}^{2}\end{array}$ & $\begin{array}{l}D \\
\mathrm{~cm}^{2} \mathrm{~s}^{-1}\end{array}$ \\
\hline $11.5 \mathrm{M} \mathrm{HNO}_{3}$ & 143 & $\begin{array}{l}3.39 \times 10^{3} \\
(12 \%)\end{array}$ & $\begin{array}{l}1.38 \times 10^{-10} \\
(5 \%)\end{array}$ & $\begin{array}{l}3.98 \times 10^{-10} \\
(39 \%)\end{array}$ & $\begin{array}{l}1.25 \times 10^{5} \\
(28 \%)\end{array}$ & $\begin{array}{l}4.29 \times 10^{-7} \\
(7 \%)\end{array}$ & $\begin{array}{l}1.14 \times 10^{5} \\
(7 \%)\end{array}$ & $\begin{array}{l}3.89 \times 10^{4} \\
(11 \%)\end{array}$ & $\begin{array}{l}4.78 \times 10^{4} \\
(1 \%)\end{array}$ & $9.43 \times 10^{-16}$ \\
\hline $\begin{array}{l}11.5 \mathrm{M} \\
\underset{\mathrm{HNO}}{\mathrm{NaF}}+0.05 \mathrm{M}\end{array}$ & 138 & $\begin{array}{l}3.84 \times 10^{3} \\
(4 \%)\end{array}$ & $\begin{array}{l}3.96 \times 10^{-10} \\
(8 \%)\end{array}$ & $\begin{array}{l}3.81 \times 10^{-10} \\
(26 \%)\end{array}$ & $\begin{array}{l}2.83 \times 10^{4} \\
(24 \%)\end{array}$ & $\begin{array}{l}7.96 \times 10^{-7} \\
(2 \%)\end{array}$ & $\begin{array}{l}1.89 \\
(10 \%)\end{array}$ & $\begin{array}{l}6.13 \times 10^{3} \\
(10 \%)\end{array}$ & $\begin{array}{l}4.13 \times 10^{4} \\
(<1 \%)\end{array}$ & $3.43 \times 10^{-6}$ \\
\hline
\end{tabular}

Table 4 Best-fit EEC parameters for air-oxidized $\mathrm{Ti}$ (with a rotational speed of $900 \mathrm{rpm}$ ) held at $\mathrm{OCP}$ in $11.5 \mathrm{M} \mathrm{HNO}_{3}$ and $11.5 \mathrm{M} \mathrm{HNO}_{3-}$ $+0.05 \mathrm{M} \mathrm{NaF}$ at room temperature 
Table 5 Corrosion rates of bare $\mathrm{Ti}$ and air-oxidized $\mathrm{Ti}\left(\mathrm{TiO}_{2}\right)$ tubes in $11.5 \mathrm{M} \mathrm{HNO}_{3}+0.05 \mathrm{M} \mathrm{NaF}$ at room temperature $\left(25^{\circ} \mathrm{C}\right)$ and boiling condition $\left(120^{\circ} \mathrm{C}\right)$ calculated from weight loss experiments

\begin{tabular}{lccc}
\hline Material conditions & Corrosion testing temperature $\left({ }^{\circ} \mathrm{C}\right)$ & Corrosion testing period $(\mathrm{h})$ & Corrosion rate $(\mathrm{mm} / \mathrm{y})$ \\
\hline Bare Ti tube & 25 & 240 & $0.15 \pm 0.03$ \\
& 120 & 48 & $3.5 \pm 0.12$ \\
Air-oxidized Ti tube & 25 & 240 & negligible \\
& 120 & 48 & $0.003 \pm 0.001$ \\
& 120 & 240 & $0.025 \pm 0.01$ \\
\hline
\end{tabular}

Fig. 8 Images of Ti tubes before and after exposure to boiling $11.5 \mathrm{M}$ $\mathrm{HNO}_{3}+0.05 \mathrm{M} \mathrm{NaF}, \mathbf{a}-\mathbf{b}$ bare $\mathrm{Ti}$; a before exposure; b exposed for $48 \mathrm{~h}$; and, c-e airoxidized $\mathrm{Ti}$; c before exposure; d exposed for $240 \mathrm{~h}$; and, e exposed for $48 \mathrm{~h}$

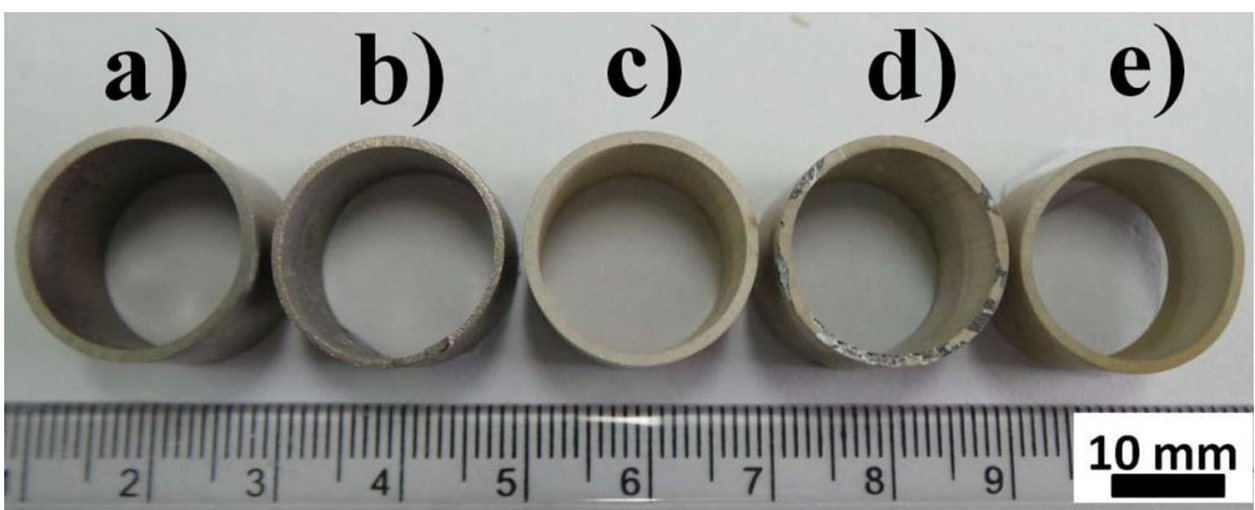

In contrast, the as-prepared condition of the air-oxidized Ti exhibits a ceramic nature with pale yellow color as shown in Fig. 8c. The weight loss of air-oxidized Ti in the same test solution under room temperature for an immersion period of $240 \mathrm{~h}$ is observed to be negligible. In comparison with Fig. 8c, a significant attack along the ringside (Fig. 8d) is observed for the air-oxidized Ti tube when exposed to the boiling condition of the solution for $240 \mathrm{~h}$. When exposed only for $48 \mathrm{~h}$ at the boiling condition, an un-attacked surface with slight discoloration (Fig. 8e) is observed for the air-oxidized Ti tube. As the immersion period is increased from $48 \mathrm{~h}$ to $240 \mathrm{~h}$, the corrosion rate increases by more than eight times for the air-oxidized Ti.

The increase in dissolution rate with immersion time may occur because, after a certain period, the dissolution of air-oxidized layer will expose the underlying $\mathrm{Ti}$ to the boiling nitric acid containing fluoride ions (Fig. 8d). It is likely that the dissolution rate will increase monotonically with immersion time and will stabilize at a high rate once the air-oxidized $\mathrm{TiO}_{2}$ layer dissolves completely. Until then, oxide layer will protect the underlying $\mathrm{Ti}$, and the dissolution of air-oxidized $\mathrm{Ti}$ in boiling nitric acid containing fluoride ions for a period of $240 \mathrm{~h}$ is observed to be 140 times lower than that for bare Ti exposed for a shorter period of $48 \mathrm{~h}$.

It is seen from Table 5 that at room temperature, in fluorinated nitric acid, the corrosion rate of air-oxidized $\mathrm{Ti}$ calculated from weight loss experiments is negligible. On the other hand, comparison of $R_{\mathrm{P}}$ values estimated from LP and EIS (listed in Tables 1, 2, 3, and 4) gives a better understanding of the improvement in corrosion resistance by the air oxidation of $\mathrm{Ti}$. It is challenging to conduct electrochemical experiments in boiling nitric acid and fluorinated nitric acid, whereas weight loss experiments give a better estimate of corrosion rate in boiling conditions. By combining the results of electrochemical experiments performed at room temperature and weight loss experiments performed in nitric acid containing fluoride ions at room temperature as well as boiling conditions, it is deduced that air-oxidized Ti exhibits better corrosion protection than $\mathrm{Ti}$ in fluorinated nitric acid.

\section{Conclusion}

The corrosion protection offered by air-oxidized Ti in nitric acid containing fluoride ions was investigated using electrochemical techniques at room temperature and the weight loss experiments at boiling temperature of $120^{\circ} \mathrm{C}$. The major conclusions of the present studies are summarized as follows:

(a) The EIS behavior of the $\mathrm{Ti}$ and air-oxidized $\mathrm{Ti}$ in nitric acid containing fluoride ions was successfully modeled with suitable electrochemical equivalent 
circuits, and the estimated $R_{P}$ values showed a good match with linear polarization. The high $R_{P}$ value of the air-oxidized Ti sample indicated a high corrosion resistance than that of $\mathrm{Ti}$. The diffusivity (D) of reacting species through the air-oxidized layer was determined from the finite-length reflective impedance parameter (B), and it was very well correlated with the corrosion behavior.

(b) The weight loss studies confirmed that the airoxidized $\mathrm{Ti}$ showed excellent corrosion protection in boiling fluorinated nitric acid as the corrosion rate is 1166 times slower than that of $\mathrm{Ti}(3.5 \mathrm{~mm} / \mathrm{y})$.

Open Access This article is distributed under the terms of the Creative Commons Attribution 4.0 International License ( http://creativecommons.org/licenses/by/4.0/), which permits unrestricted use, distribution, and reproduction in any medium, provided you give appropriate credit to the original author(s) and the source, provide a link to the Creative Commons license, and indicate if changes were made.

\section{References}

1. Natarajan R, Raj B, J Nucl Sci Technol 44 (2007) 393.

2. Bernard C, Mouroux J P, Decours J, Demay R, Simonnet J, Zirconium-made equipment for the new La Hague reprocessing plants, Japan Atomic Industrial Forum, Japan (1991).

3. Jayaraj J, Krishnaveni P, Krishna D N G, Mallika C, Mudali U K, J Nucl Mater 473 (2016) 157.

4. Uriarte A L, Rainey R H, Dissolution of high-density UO2, $\mathrm{PuO} 2$, and UO2-PuO2 pellets in inorganic acids, Technical Report ORNL-3695, The U.S. Atomic Energy Commission, Washington $(1965) \mathrm{p} 1$.

5. Jayaraj J, Nanda Gopala Krishna D, Mallika C, Kamachi Mudali U, Trans Indian Inst Metals 71 (2018) 521.

6. Raj B, Mudali U K, Prog Nucl Energy 48 (2006) 283.

7. Kelly J J, Electrochimica Acta 24 (1979) 1273.

8. Kong D -S, Feng Y -Y, J Electrochem Soc 156 (2009) C283.

9. Fasmin F, Praveen B, Ramanathan S, J Electrochem Soc 162 (2015) H604.

10. Lu X, Zhao Z, Leng Y, Mater Sci Eng C 27 (2007) 700.

11. Yousefpour M, Afshar A, Chen J, Zhang X, Mater Design 28 (2007) 2154.

12. Pattanayak D K, Kawai T, Matsushita T, Takadama H, Nakamura T, Kokubo T, J Mater Sci Mater Med 20 (2009) 2401.

13. Fazel M, Salimijazi H R, Shamanian M, ACS Appl Mater Interfaces 10 (2018) 15281.

14. Montenero A, Gnappi G, Ferrari F, Cesari M, Salvioli E, Mattogno L, Kaciulis S, Fini M, J Mater Sci 35 (2000) 2791.

15. Kim H -W, Koh Y-H, Li L-H, Lee S, Kim H -E, Biomaterials 25 (2004) 2533.
16. Liu X, Chu P K, Ding C, Mater Sci Eng R Rep 47 (2004) 49.

17. Hee A C, Jamali S S, Bendavid A, Martin P J, Kong C, Zhao Y, Surf Coat Technol 307 (2016) 666.

18. Mittal M, Natha S K, Prakash S, J Min Mater Charact Eng 10 (2011) 1041.

19. Krupa D, Baszkiewicz J, Kozubowski J A, Barcz A, Sobczak J W, Biliński A, Lewandowska-Szumieł M, Rajchel B, Biomaterials 22 (2001) 2139.

20. Krupa D, Baszkiewicz J, Kozubowski J A, Barcz A, Sobczak J W, Biliński A, Lewandowska-Szumieł M, Rajchel B, Biomaterials 23 (2002) 3329.

21. Schutz R W, Covington L C, Corrosion 37 (1981) 585.

22. Kumar S, Narayanan T S N S, Ganesh Sundara Raman S, Seshadri S K, Mater Sci Eng C 30 (2010) 921.

23. Shankar A R, Karthiselva N S, Mudali U K, Surf Coat Technol 235 (2013) 45.

24. Vetrivendan E, Jayaraj J, Ningshen S, Mallika C, Kamachi Mudali U, J Therm Spray Technol 27 (2018) 512.

25. Stern M, Geary A L, J Electrochem Soc 104 (1957) 56.

26. Guidelines for avoiding intergranular corrosion and stress corrosion in austenitic stainless steel components of fuel reprocessing plants, Regulatory Guide 3.37, U.S. Nuclear Regulatory Commission, USA (1975) p 1.

27. Kofstad P, Hauffe K, Kjollesdal H, Acta Chemica Scandinavica 12 (1958) 239.

28. Jayaraj J, Thinaharan C, Ningshen S, Mallika C, Kamachi Mudali U, Intermetallics 89 (2017) 123.

29. Jayaraj J, Ravi Shankar A, Kamachi Mudali U, Electrochimica Acta 85 (2012) 210.

30. Knacke O, Kubaschewski O, Hesselmann K, Thermochemical Properties of Inorganic Substances, 2nd Ed, Springer, New York (1991).

31. Sutter E M M, Goetz-Grandmont G J, Corros Sci 30 (1990) 461.

32. Brug G J, van den Eeden A L G, Sluyters-Rehbach M, Sluyters J H, J Electroanal Chem Interfacial Electrochem 176 (1984) 275.

33. Brug G J, Sluyters-Rehbach M, Sluyters J H, Hemelin A, J Electroanal Chem Interfacial Electrochem 181 (1984) 245.

34. Hirschorn B, Orazem M E, Tribollet B, Vivier V, Frateur I, Musiani M, Electrochimica Acta 55 (2010) 6218.

35. Lasia A, Electrochemical impedance spectroscopy and its applications, Springer, New York (2014).

36. Orazem M E, Tribollet B, Electrochemical impedance spectroscopy, 1st ed., Wiley-Interscience, United States (2008).

37. Harrington D A, van den Driessche P, J Electroanal Chem $\mathbf{5 6 7}$ (2004) 153.

38. Franceschetti D R, Macdonald J R, J Electroanal Chem Interfacial Electrochem 82 (1977) 271.

39. Ranjith P M, Rao M T, Sapra S, Suni I I, Srinivasan R, J Electrochem Soc 165 (2018) C258.

40. Mandula T R, Srinivasan R, J Solid State Electrochem (2017) 1.

41. Amrutha M S, Rao M T, Ramanathan S, J Electrochem Soc $\mathbf{1 6 5}$ (2018) C162.

42. Wagner N, Friedrich K A, Fuel Cells 9 (2009) 237.

Publisher's Note Springer Nature remains neutral with regard to jurisdictional claims in published maps and institutional affiliations. 